\title{
Herbicidal control of pricklypear cactus in western Texas
}

\author{
JOSEPH L. PETERSEN, DARRELL N. UECKERT, AND ROBERT L. POTTER
}

\section{Abstract}

The recommended practice for pricklypear (Opuntia spp.) control in western Texas has been aerial spraying with a 1:1 mixture of 2,4,5-T [(2,4,5-trichlorophenoxy)acetic acid] and picloram (4 amino-3,5,6-trichloro-2-pyridinecarboxylic acid) at $0.56 \mathrm{~kg} / \mathrm{ha}$ in late sprinf-early summer. This practice did not consistently control pricklypear. Experiments were conducted at 2 locations to determine if eficacy of the herbicide mixture could be improved by increasing the rate or by spraying at night. The herbicide mixture was applied at 0.56 and $1.12 \mathrm{~kg} / \mathrm{ha}$ to dense pricklypear stands in morning and near midnight in December, June, August, and October. The high rate killed more Lindheimer pricklypear $(O$. Indheimeri) and Edwards pricklypear (O. edwardsii) growing on clay loam soils compared to the low rate during most seasons. The higher rate did not inerease control of hybrid pricklypear growing on clay soils sufficiently to justify the added treatment cont or to satisfy the management objectives of most ranchers. Night treatments killed significantly more pricklypear than daytime treatments only during late spring-early summer. The pricklypear species and hybrids were most susceptible to herbicide applications in late summer and early autumn and least susceptible to those in late spring-early summer. The efficacy of early winter treatments was intermediate.

Key Words: Opuntia, range improvements, 2,4,5-T, picloram, photosynthates

Pricklypear (Opuntia spp.) occurs on about $28 \%$ of the rangeland (10.3 million ha) in Texas (Lundgren et al. 1981). Dense stands of pricklypear interfere with handling and movement of livestock (Dameron and Smith 1939), utilization of forages by livestock (Bement 1968, Price et al. 1985), and compete with desirable forage plants. Pricklypear provides emergency livestock feed during drought (Shoop et al. 1977), but the spines cause bacterial infection in the mouths and gastrointestinal tracts of livestock and the seeds cause rumen impaction (Migaki et al. 1969, Merrill et al. 1980). Weather, soils, grazing, insects, fire, and interactions among these factors influence the abundance of pricklypear (Thomas and Darrow 1956, Houston 1963, Hyder et al. 1966, Bement 1968, Bunting et al. 1980).

The recommendation for herbicidal control of pricklypear in the Rolling Plains and Edwards Plateau resource areas of Texas has been aerial spraying with a $1: 1$ mixture of $2,4,5-T[(2,4,5-$ trichlorophenoxy)acetic acid] and picloram (4-amino-3,5,6-trichloro-2-pyridinecarboxylic acid) at $0.56 \mathrm{~kg}$ ae/ha during late spring or early summer (Hoffman 1975). A higher rate (1.12 kg/ ha) was recommended for the South Texas Plains. These recommendations were developed from observations made in numerous experiments and demonstrations in which honey mesquite (Prosopis glandulosa Torr. var. glandulosa) was the primary target of herbicide treatments applied during late spring and early summer. Inconsistent control of pricklypear following commercial applications of the herbicide mixture at the recommended time and rate, and widespread concern that pricklypear had become the primary

\footnotetext{
Authors are research associate, professor, and former research associate, respectively, Texas Agricultural Experiment Station, 7887 N. Hwy 87, San Angelo, Texas 76901. Potter's curtent address is Institute of Ecology, University of Georgia, Athens 30602.

Approved by the Director, Texas Agricultural Experiment Station as TA-22115. The authors express appreciation to Mrs. J.P. Miller and Bub Miller for providing land for this research in Coleman County and to Dr. C.E. Gates, Statistical Services, Texas Agr. Exp. Sta., for assistance with statistical analyses.

Manuscript accepted 29 February 1988.
}

weed problem on many ranches suggested that recommendations for herbicidal control of pricklypear in the Rolling Plains and Edwards Plateau should be re-examined.

Physiological and morphological characteristics of pricklypear are quite different from those of most brush and weed species and these differences influence the behavior of herbicides. The limited number of stomata, thick wax cuticle, and high water-binding ability of cell mucilage in pricklypear are associated with the plants' low nutrient requirements for growth, slight photosynthetic activity, slow translocation, and low transpiration rates (Chow et al. 1966a). Absorption of herbicides into cladophylls and roots of pricklypear and subsequent translocation is very slow and limited compared to that observed in herbaceous plants (Chow et al. 1966b, H.S. Mayeux, Jr., unpublished data). Night application of some herbicides as wetting sprays killed more plains pricklypear (O. polyacantha Haw.) than daytime applications, presumably because stomata were open at night and closed during the day (Schuster 1971). We hypothesized that herbicide applications during late summer, autumn, and winter might kill more Lindheimer pricklypear $(O$. lindheimeri Engelm.) than late spring or early summer applications because photosynthates are replenished in the roots, crowns, and mature cladophylls during late summer through winter (Potter et al. 1986). Photosynthates from these stuctures are translocated upward into new cladophylls and fruits during spring through midsummer. The primary objectives of this research were to determine if pricklypear control with broadcast sprays of the mixture of 2,4,5-T and picloram could be improved by using a rate greater than that currently recommended and / or by applying the herbicides at night. The experiments were designed to determine the relative susceptibility of pricklypear to the herbicide mixture applied in various seasons of the year.

\section{Materials and Methods}

Experiments were conducted on an Angelo clay loam (fine, mixed, thermic Torrertic Calciustolls) in western Tom Green County, about $8 \mathrm{~km}$ northwest of San Angelo, Texas, and on undifferentiated Tarrant (clayey-skeletal, montmorillonitic, thermic Lithic Calciustolls) and Purves (clayey, montmorillonitic, thermic Lithic Calciustolls) clays in central Coleman County, about $10 \mathrm{~km}$ northeast of Coleman, Texas. Long-term average annual precipitation is $52 \mathrm{~cm}$ at San Angelo and $69 \mathrm{~cm}$ at Coleman.

The San Angelo study site supported $7 \%$ cover of a mixture of Lindheimer and Edwards pricklypear (O. edwardsii Grant \& Grant). Associated vegetation included honey mesquite, lotebush [Ziziphus obtusifolia (Hook ex. Torr. \& Gray)], tobosagrass [Hilaria mutica (Buckl.) Benth], common curlymesquite [ $\boldsymbol{H}$. belangeri (Steud.) Nash], and buffalograss [Buchloe dactyloides (Nutt.) Engelm.]. Soils at the San Angelo site contained $38 \%$ clay, $34 \%$ silt. $28 \%$ sand, $0.9 \%$ coarse $(>2 \mathrm{~mm}$ ) fraction, $2.8 \%$ organic matter, and had a pH of 7.7. The Coleman study site supported $6 \%$ cover of a hybrid population of $O$. lindheimeri $\times(O$. edwardsii $-O$. phaeacantha var. major Engelm.). Species in the $O$. phaeacantha group often hybridize and hybrids are common in central Texas (Grant and Grant $1979 \mathrm{a}, \mathrm{b})$. Associated vegetation at the Coleman County site included honey mesquite, liveoak (Quercus fusiformis Small), sideoats grama [Bouteloua curtipendula (Michx.) Torr.], common curlymesquite, Texas wintergrass (Stipa leucotricha Trin. \& 
Table 1. Dnvironmental variables recorded at study sttes near San Angelo (SA) and Coleman (C), Texes during applicatione of a 1:1 mixture of 2,4,5-T and picloram for pricklypear control.

\begin{tabular}{|c|c|c|c|c|c|c|c|c|c|c|c|c|}
\hline & & \multirow[b]{3}{*}{ Time of day } & \multicolumn{10}{|c|}{ Environmental variables } \\
\hline & & & \multicolumn{2}{|c|}{$\begin{array}{c}\text { Ambient } \\
\text { temperature }\end{array}$} & \multicolumn{2}{|c|}{$\begin{array}{l}\text { Relative } \\
\text { humidity }\end{array}$} & \multicolumn{2}{|c|}{$\begin{array}{l}\text { Wind } \\
\text { speed }\end{array}$} & \multicolumn{2}{|c|}{$\begin{array}{l}\text { Soil temperature } \\
\text { at } 2.5 \mathrm{~cm}\end{array}$} & \multicolumn{2}{|c|}{$\begin{array}{l}\text { Gravimetric soi } \\
\text { water content }\end{array}$} \\
\hline \multicolumn{2}{|c|}{ Date of application } & & SA & C & SA & $\mathbf{C}$ & SA & C & SA & $\mathbf{C}$ & SA & $\mathbf{C}$ \\
\hline \multirow[b]{2}{*}{ December } & & (hr) & \multicolumn{2}{|c|}{$\left({ }^{\circ} \mathrm{C}\right)$} & \multicolumn{2}{|c|}{$(\%)$} & \multicolumn{2}{|c|}{$(\mathbf{k m} / \mathbf{h r})$} & \multicolumn{2}{|c|}{$\left({ }^{\circ} \mathrm{C}\right)$} & \multicolumn{2}{|c|}{$(\%)$} \\
\hline & 1981 & 1130 & 15 & 18 & 34 & 74 & 8 & 10 & 9 & 14 & \multirow{2}{*}{17} & \multirow{2}{*}{25} \\
\hline June & 1982 & $\begin{array}{l}2230 \\
0900\end{array}$ & $\begin{array}{r}7 \\
27\end{array}$ & $\begin{array}{l}10 \\
26\end{array}$ & $\begin{array}{l}79 \\
70\end{array}$ & $\begin{array}{r}100 \\
77\end{array}$ & $\begin{array}{l}0 \\
8\end{array}$ & $\begin{array}{l}0 \\
5\end{array}$ & $\begin{array}{r}7 \\
26\end{array}$ & $\begin{array}{l}10 \\
26\end{array}$ & & \\
\hline August & 1982 & $\begin{array}{l}0200 \\
0930\end{array}$ & $\begin{array}{l}25 \\
29\end{array}$ & $\begin{array}{l}25 \\
27\end{array}$ & $\begin{array}{l}71 \\
62\end{array}$ & $\begin{array}{l}76 \\
62\end{array}$ & $\begin{array}{r}0 \\
10\end{array}$ & $\begin{array}{r}3 \\
13\end{array}$ & $\begin{array}{l}26 \\
29\end{array}$ & $\begin{array}{l}25 \\
31\end{array}$ & 13 & 22 \\
\hline \multirow[t]{2}{*}{ October } & \multirow[t]{2}{*}{1982} & $\begin{array}{l}0100 \\
1000\end{array}$ & $\begin{array}{l}27 \\
20\end{array}$ & $\begin{array}{l}28 \\
14\end{array}$ & $\begin{array}{l}60 \\
58\end{array}$ & $\begin{array}{l}48 \\
73\end{array}$ & $\begin{array}{l}0 \\
6\end{array}$ & $\begin{array}{r}14 \\
6\end{array}$ & $\begin{array}{l}30 \\
16\end{array}$ & $\begin{array}{l}32 \\
14\end{array}$ & 13 & 17 \\
\hline & & 0130 & 10 & 10 & 82 & 77 & 0 & 0 & 15 & 15 & 14 & 23 \\
\hline
\end{tabular}

"Dates of herbicide application were 8 December 1981, 10 June 1982, 3 August 1982, and 14 October 1982 at Coleman and 15 December 1981, 11 June 1982, 4 August 1982, and 15 October 1982 at San Angelo.

Soil water content is the average of 9 samples taken at $15-\mathrm{cm}$ increments to a $45-\mathrm{cm}$ depth.

Rupr.), and Japanese brome (Bromus japonicus Thunb. ex. Murr.). Soils at the Coleman site contained $51 \%$ clay, $36 \%$ silt, $13 \%$ sand, $4 \%$ coarse fraction, $4.4 \%$ organic matter, and had a pH of 6.5. Pricklypear classification follows that of Grant and Grant (1979a).

Herbicide treatments were applied to $12.2-$ by $30.5-\mathrm{m}$ plots arranged as randomized complete blocks in factorial design with 3 replications. A 1:1 mixture of the butoxyethanol ester of 2,4,5-T and the triisopropanolamine salt of picloram was applied at 0.56 and $1.12 \mathrm{~kg} / \mathrm{ha}$ as a foliar spray using a tractor-mounted sprayer with a $6.1-\mathrm{m}$ boom. The herbicide mixture was applied in $140 \mathrm{~L} / \mathrm{ha}$ of a $1: 14$ (v:v) diesel fuel/water emulsion with $0.1 \%$ (v:v) commercial emulsifier. Treatments were applied at about $2.2 \mathrm{hr}$ after sunrise and $4.5 \mathrm{hr}$ after sunset as separate experiments on 15 December 1981, 11 June, 4 August, and 15 October 1982 at San Angelo; and on 8 December 1981, 10 June, 3 August, and 14 October 1982 at Coleman (Table 1). An untreated plot was included in each block on each application date.

Intercept of live pricklypear was measured along 2, permanently marked, 32.6-m transects in each plot the day of herbicide application and annually for 3 years after treatment. Treatment efficacy was quantified as percentage reduction of live pricklypear canopy cover. Percentage data were transformed by $\sin ^{-1} \sqrt{X}$, then subjected to analyses of variance. Means for time of day (daytime vs. nighttime) and means for application rates were separated by LSD tests $(P \leq 0.05)$ for each date of application and location.

The developmental stage of pricklypear was recorded on each date of treatment. Environmental parameters recorded during herbicide applications included air temperature, relative humidity, wind speed, soil temperature at a $2.5-\mathrm{cm}$ depth, and soil water contents. Soil water contents were determined gravimetrically from 9 samples taken at $15-\mathrm{cm}$ depth increments to $45 \mathrm{~cm}$ at each study site. Precipitation was measured with a rain gauge at the San Angelo site and obtained from a U.S. Army Corps of Engineers recording station about $16 \mathrm{~km}$ from the Coleman site.

\section{Results and Discussion}

All pricklypear cladophylls were mature and there were no fruits present when herbicide treatments were applied in December 1981. Fruits were green, and new cladophylls and spines were rapidly enlarging at treatment in June 1982. Fruits were mostly red or purple and cladophylls and spines were almost fully expanded at treatment in August 1982. New cladophylls were fully expanded and fruits were dropping at time of October 1982 treatments. Based on our data for Lindeheimer pricklypear (Potter et al. 1986), we presumed that photosynthates were being replenished in pricklypear roots, crowns, and mature cladophylls when treatments were applied in December 1981, August 1982, and October 1982 and that photosynthates were being depleted (translocated upward) from these structures at treatment in June 1982. Soils were relatively dry when herbicides were applied in June, August, and October at San Angelo and in August at Coleman, but conditions were believed to be favorable for pricklypear growth at all treatment dates (Table 1). Rainfall was sufficient to move the picloram into the soil within 60 days after all herbicide applications (Table 2). Picloram applied at $0.28 \mathrm{~kg} / \mathrm{ha}$ persists in soils for 1 year in semiarid environments (Scifres et al. 1971).

Table 2. Cumulative rainfall $(\mathrm{cm})$ received $10,30,60$, and 90 days after applications of a 1:1 mixture of 2,4,5-T and picloram near San Angelo and Coleman, Texas at 4 treatmeat dates.

\begin{tabular}{|c|c|c|c|c|}
\hline \multirow{2}{*}{$\begin{array}{l}\text { Days after } \\
\text { treatment }\end{array}$} & \multicolumn{4}{|c|}{ Treatment dates } \\
\hline & December & June & August & October \\
\hline \multirow[b]{2}{*}{$\begin{array}{l}10 \\
30 \\
60 \\
90\end{array}$} & \multicolumn{4}{|c|}{ San Angelo } \\
\hline & $\begin{array}{l}0.0 \\
0.6 \\
1.9 \\
5.7\end{array}$ & $\begin{array}{r}9.8 \\
22.3 \\
23.5 \\
23.5\end{array}$ & $\begin{array}{l}1.1 \\
1.1 \\
2.1 \\
3.7\end{array}$ & $\begin{array}{l}0.1 \\
0.1 \\
4.6 \\
6.7\end{array}$ \\
\hline $\begin{array}{l}10 \\
30 \\
60 \\
90\end{array}$ & $\begin{array}{l}0.2 \\
0.2 \\
4.5 \\
7.6\end{array}$ & $\begin{array}{r}9.7 \\
22.9 \\
27.8 \\
28.0\end{array}$ & $\begin{array}{l}3.9 \\
3.9 \\
6.5 \\
7.9\end{array}$ & $\begin{array}{l}0.1 \\
0.1 \\
7.5 \\
7.5\end{array}$ \\
\hline
\end{tabular}

Phytotoxicity of the herbicide mixture to pricklypear was not fully manifested until 3 years after treatment (Fig. 1). Live pricklypear cover on untreated plots increased by $47 \%$ at San Angelo and by $38 \%$ at Coleman, compared to initial cover values; thus growing conditions for pricklypear during the 3-year period were favorable. This substantial increase in live pricklypear cover on untreated rangeland confirmed the concern that pricklypear was increasing in abundance in the region.

The $1.12 \mathrm{~kg} / \mathrm{ha}$ rate of $2,4,5-\mathrm{T}+$ picloram killed significantly $(P \leq 0.05)$ more pricklypear than the $0.56 \mathrm{~kg} /$ ha rate following December, June, and August applications at San Angelo, but only 


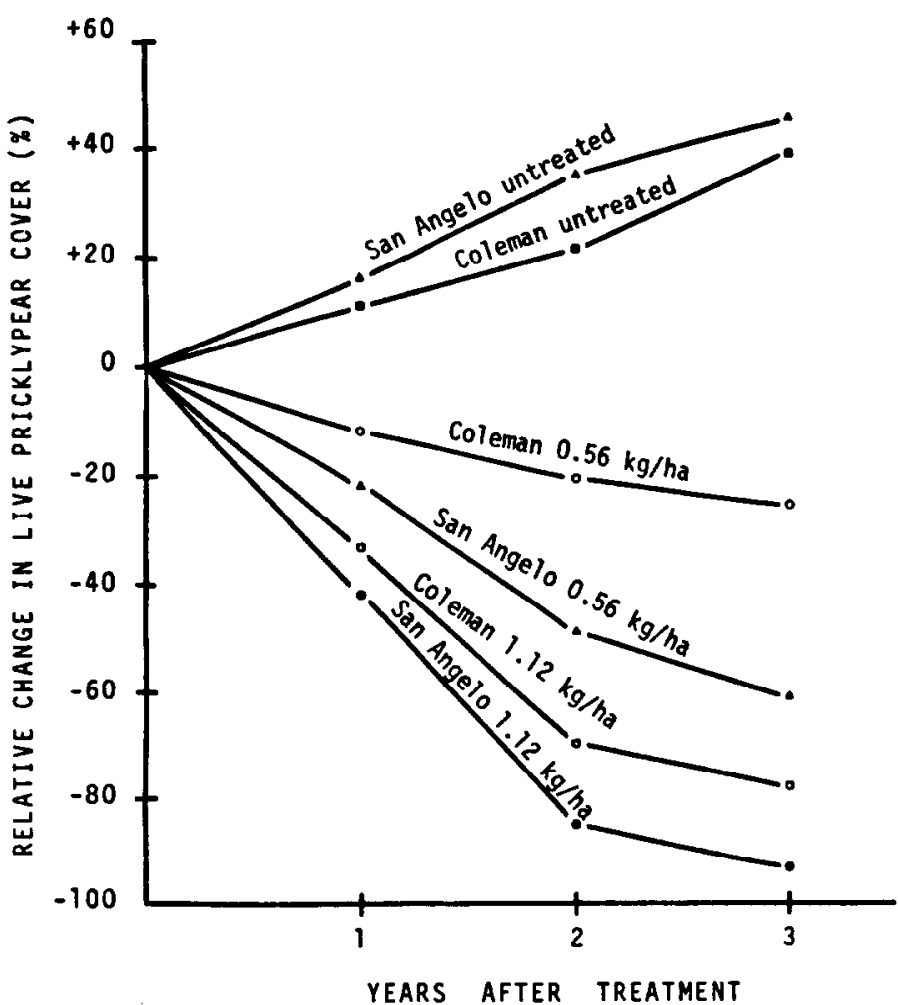

Fig. 1. Relative changes (\%) in live pricklypear cover for 3 years following broadcast applications of a 1:1 mixture of 2,4,5-T and picloram at 0.56 and $1.12 \mathrm{~kg} / \mathrm{ha}$ and on untreated rangeland at study sites near San Angelo and Coleman, Texas. Data were averaged over daytime and nightime treatments in December 1981, June 1982, August 1982, and October 1982.

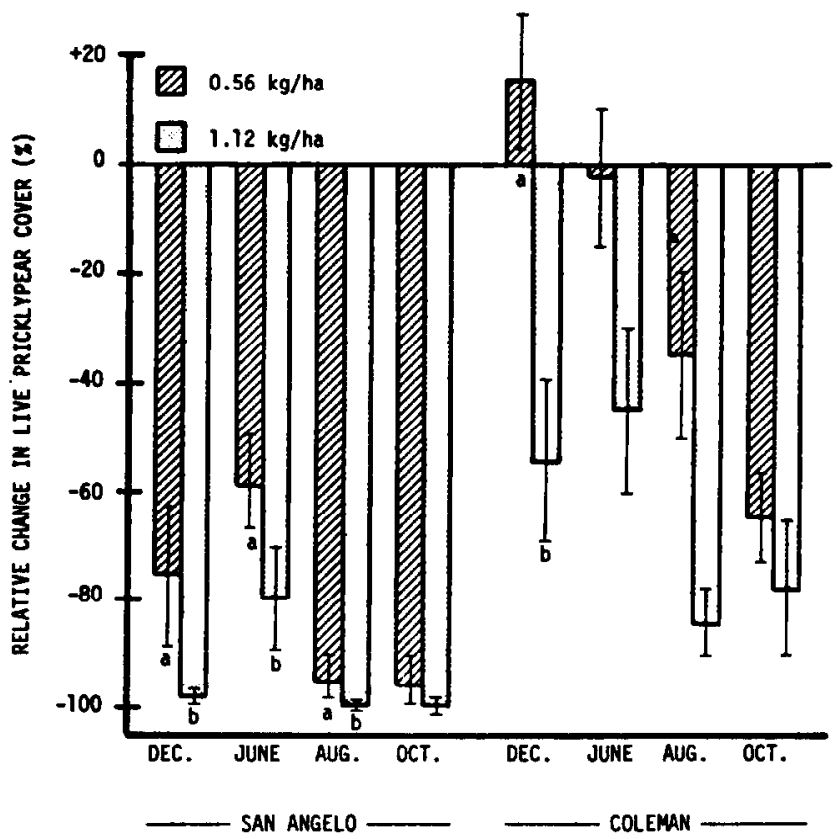

Fig. 2. Relative changes (\% \pm S.E.) in live pricklypear cover 3 years after broadcast applications of a 1:1 mixture of 2,4,5-T and picloram at 0.56 and $1.12 \mathrm{~kg} / \mathrm{ha}$ in December, June, August, and October at study sites near San Angelo and Coleman, Texas. Data are averaged over daytime and nighttime treatments. Different lower case letters within a treatment date and site indicate significant $(\mathrm{P} \leq 0.05)$ difference between rates according to LSD tests.

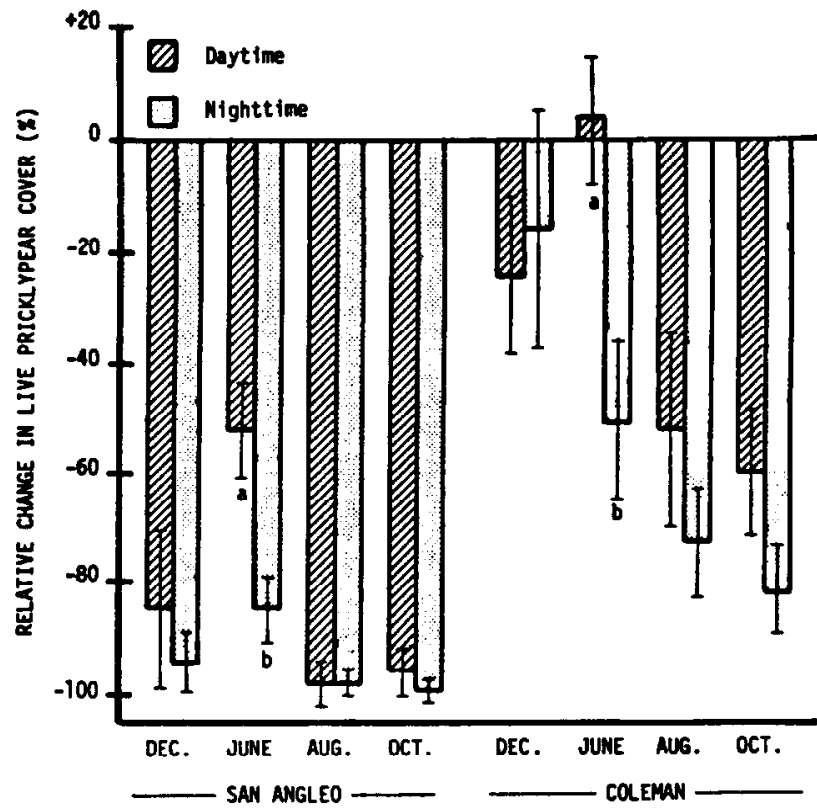

Fig. 3. Relative changes (\% \pm S.E.) in live pricklypear cover 3 years after broadcast applications of a $1: 1$ mixture of 2,4,5-T and picloram at daytime and nighttime in December, June, August, and October at study sites near San Angelo and Coleman, Texas. Data are averaged over 0.56 and $1.12 \mathrm{~kg} / \mathrm{ha}$ rates of application. Different lower case letters within a treatment date and site indicate significant $(\mathbf{P} \leq 0.05)$ difference between day and night treatments according to LSD tests.

following December applications at Coleman (Fig. 2). The data suggest a trend of greater control with the high rate across all treatment seasons and thus support the current recommendation to use $0.56 \mathrm{~kg} / \mathrm{ha}$ of picloram for pricklypear control (Welch 1984). Variation in treatment efficacy was lower for the high rate compared to the low rate at San Angelo, but not at Coleman. August and October applications of the $0.56 \mathrm{~kg} / \mathrm{ha}$ rate were highly effective at the San Angelo site, reducing live pricklypear cover by $91 \%$. The higher rate may not achieve a sufficient kill of hybrid pricklypear growing on clay soils to justify treatment costs or to satisfy the management objectives of many ranchers.

Nighttime applications of 2,4,5-T + picloram killed more $(P \leq 0.05)$ pricklypear than daytime applications only following June treatments (Fig. 3). Environmental conditions were very similar when night and day treatments were applied in June (Table 1). Differential treatment responses may have been associated with greater stomatal penetration by the herbicide mixture at night compared to daytime. Gas exchange activity at night may be greater in the spring than at other seasons among western Texas pricklypears. Schuster (1971) found that night applications of 2,4,5-T and silvex [2-(2,4,5-trichlorophenoxy)propanoic acid] as wetting sprays during June and July killed more plains pricklypear than day applications, but the treatments were not evaluated at other seasons. The importance of penetration of aqueous spray solutions through stomata has been questioned (Currier and Dybing 1959), but stomatal penetration may be seasonally important in plants with thick wax cuticles. Night applications of the herbicide mixture in late spring-early summer were no more effective than day applications in late summer or early autumn.

Experiments were not repeated over years in this study, thus pricklypear control means for seas ons (months) could not be compared statistically. However, means ( \pm S.E.) for the 4 treatment times are shown in Figures 2 and 3 . These data are not conclusive, but suggest that populations of Lindheimer and Edwards pricklypear at San Angelo and pricklypear hybrids at Coleman were most susceptible to late summer and autumn applications of $2,4,5-\mathrm{T}+$ 
picloram, and that the pricklypears were least susceptible to late spring applications. We propose that the apparent increased control after late summer and autumn treatments may be associated with greater translocation of herbicide into plant structures bearing perennating buds (crowns and mature cladophylls) during subsequent months, and that the decreased control following spring applications was associated with upward translocation of herbicides into new cladophylls and fruits (Potter et al. 1986). Additional research is needed to substantiate this hypothesis and to definitively bracket the period(s) of greatest susceptibility of pricklypear to picloram.

The species of pricklypear at San Angelo were moderately susceptible while the hybrids at Coleman were resistant to December herbicide treatments. Environmental and/or other plant growth factors may be more important than carbohydrate translocation and sink/source relationships during late autumn and winter. Air and surface soil temperatures were markedly lower during December herbicide applications than during June or August applications, but only slightly lower or similar to those during October applications (Table 1). Prevailing ambient temperatures during the weeks subsequent to herbicide applications may be more important than those at time of treatment for plants such as pricklypear, which absorb and translocate herbicides very slowly. Our data appear to contradict the current recommendation that picloram should only be applied when air temperatures are above $15.5^{\circ} \mathrm{C}$ (Welch 1984). Applications of 2,4,5-T + picloram at air temperatures of $10^{\circ} \mathrm{C}$ in October (nighttime) (Table 1) killed 81 and $99 \%$ (averaged over rates) of the pricklypear at the Coleman and San Angelo sites, respectively (Fig. 3).

The pricklypear hybrids at the Coleman site were clearly more resistant to the herbicide treatments than the distinct species at San Angelo. Soils at Coleman had $13 \%$ higher clay contents and $1.6 \%$ higher organic matter contents than soils at San Angelo. Efficacy of soil-active herbicides such as picloram decreases as soil clay and organic matter contents increase (Klingman and Ashton 1982). Also, standing crops of herbaceous vegetation and mulch were greater at the Coleman site, which may have reduced deposition of herbicide on the pricklypear and soil surfaces. Site differences such as these have undoubtedly been associated with observed variability in effectiveness of commercial herbicide applications. Furthermore, hybridization might increase herbicide resistance by affecting rate of growth, morphology, physiology, and biochemistry of pricklypear.

Earlier research demonstrated that applications of 2,4,5-T alone were not effective for pricklypear control unless applied as wetting sprays (individual plant treatment), at high rates $\geq 2.2 \mathrm{~kg} / \mathrm{ha}$ ), repeated applications at high rates, or at high rates following mechanical bruising of the pricklypear (Hoffman 1967, Wicks et al. 1969 , Schuster 1971). We believe that pricklypear mortality in this study was caused by picloram. Aerial applications of picloram are currently used for pricklypear control.

\section{Literature Cited}

Bement, R.E. 1968. Plains pricklypear: Relation to grazing intensity and blue grama yield on central Great Plains. J. Range Manage. 21:83-86.

Bunting, S.C., H.A. Wright, and L.F. Neuenschwander. 1980. Long-term effects of fire on cactus in the southern mixed prairie of Texas. J. Range Manage. 33:85-88.

Chow, P.N., O.C. Bumeide, and T.L. Lavy. 1966a. Physiological studies with prickly pear. Weeds $14: 58-62$.

Chow, P.N., O.C. Burnalde, T.L.Lavy, and H.W. Knoche. 1966b. Absorption translocation, and metabolism of silvex in prickly pear. Weeds $14: 38-41$

Currier, H.B., and C.D. Dybing. 1959. Foliar penetration of herbicidesreview and present status. Weeds 7:195-213.

Dameron, W.H., and H.P. Smith. 1939. Pricklypear eradication and control. Texas Agr. Exp. Sta. Bull. 575.

Grant, V., and K.A. Grant. 1979a. Systematics of the Opuntia phaecantha group in Texas. Bot. Gaz. 140:199-207.

Grant, V., and K.A. Grant. 19796. Hybridization and variation in the Opuntia phaecantha group in central Texas. Bot. Gaz. 140:208-215.

Hoffman, G.0. 1967. Controlling pricklypear in Texas. Down to Earth 23:9-12. The Dow Chemical Co., Midland, Mich.

Hoffman, G.O. 1975. Control and management of mesquite on rangeland. Texas Agr. Ext. Serv. Misc. Pub. 386.

Houston, W.R. 1963. Plains pricklypear, weather, and grazing in the northern Great Plains. Ecology 44:569-574.

Hyder, D.N., R.E. Bement, E.E. Remmenga, and C. Terwilliger, Jr. 1966. Vegetation-soils and vegetation-grazing relations from frequency data. J. Range Manage. 19:11-17.

Klingman, G.C., and F.M. Ashton. 1982. Herbicides and the soil. p. 80-94. in:G.C. Klingman and F.M. Ashton (eds.) Weed Science: Principles and Practices, 2nd Ed. John Wiley and Sons, New York.

Lundegren, G.K., R.E. Whitson, D.N. Ueckert, F.E. Gilstrap, and C.W. Livingaton, Jr. 1981. Assessment of the pricklypear problem on Texas rangelands. Texas Agr. Exp. Sta. Misc. Pub. 1483.

Merrill, L.B., C.A. Taylor, Jr., R. Dusek, and C.W. Livingaton. 1980. Sheep losses from range with heavy pricklypear infestation. p. 91. In: D.N. Ueckert and J.E. Huston (eds.). Rangeland Resources Research. Texas Agr. Exp. Sta. Consol. Prog. Rep. 3665.

Migakd, G., L.E. Hinson, G.D. Imes, Jr, and F.M. Garner. 1969. Cactus spines in tongues of slaughtered cattle. J. Amer. Vet. Med. Assoc. 155:1489-1492.

Potter, R.L., J.L. Petersen, and D.N. Ueckert. 1986. Seasonal trends of total nonstructural carbohydrates in Lindheimer pricklypear (Opuntia lindheimeri). Weed Sci. 34:361-365.

Price, D.L., R.K. Heitschmidt, S.A. Dowhower, and J.R. Frasure. 1985. Rangeland vegetation response following control of brownspine pricklypear (Opuntia phaecantha) with herbicides. Weed Sci. 33:640-643.

Schuster, J.L. 1971. Night applications of phenoxy herbicides on plains pricklypear. Weed Sci. 19:585-587.

Sclifes, C.J., R.R. Hahn, J. Diaz-Colon, and M.G. Merkle. 1971. Picloram persistence in semiarid rangeland soils and water. Weed Sci. 19:381-384.

Shoop, M.C., E.J. Alford, and H.F. Mayland. 1977. Plains pricklypear is a good forage for cattle. J. Range Manage. 30:12-17.

Thoma, G.W., and R.A. Darrow. 1956. Response of pricklypear to grazing and control measures. Texas Range Station, Barnhart. Texas Agr. Exp. Sta. Prog. Rep. 1873.

Welch, T.G. 1984. Suggestions for chemical weed and brush control on rangeland. Texas Agr. Ext. Serv. Bull. 1466.

Wicks, G.A., C.R. Fenster, and O.C. Burnside. 1969. Selective control of plains pricklypear in rangeland with herbicides. Weed Sci. 17:408-411. 